\title{
Site index curves for the golden oak species (Quercus alnifolia)
}

\author{
Curvas de índice de sitio para la especie roble dorado (Quercus alnifolia)
}

\author{
Petros Petrou a, Kyriaki Kitikidou ${ }^{\text {b,* }}$, Elias Milios ${ }^{\text {b }}$, Joanna Koletta ${ }^{\text {b }}$, Andreas Mavroyiakoumos ${ }^{\text {a }}$ \\ ${ }^{\text {a }}$ Cyprus Forestry College, Prodromos 4841, Cyprus. \\ *Corresponding author: ${ }^{\mathrm{b}}$ Democritus University of Thrace, Department of Forestry and Management of the Environment and \\ Natural Resources, Pandazidou 193, 68200, Orestiada, Greece, phone: 0030-2552041179, kkitikid@fmenr.duth.gr
}

\begin{abstract}
SUMMARY
The golden oak (Quercus alnifolia) is the most ecologically important endemic species of Cyprus; therefore, the development of site index curves for classification of golden oak trees to site qualities will be useful for the rational management and monitoring of natural habitats of the golden oak. The objective of this work was to develop site index curves for the golden oak species. From areas of natural spread of golden oak in Cyprus, sixty dominant trees were selected randomly and cut; for each sampled tree a stem analysis was conducted. Forty-two linear and non-linear regression models were tested for fit-to-height/age data; and from these, the most suitable was chosen for the development of a guide curve. Afterwards, a set of anamorphic site indices was created based on this curve. The selected height/age model was: $\hat{h}=\frac{t^{2}}{29.576+5.315 t+0.091 t^{2}}$. At the base age of 40 years, the selected model estimated a height of $4 \mathrm{~m}$ (SI4). Using the selected model as the guide curve for the development of anamorphic site index curves, we drew two more curves: SI3 (at the age of 40 years the estimated tree height is $3 \mathrm{~m}$ ) and SI5 (at the age of 40 years the estimated tree height is $5 \mathrm{~m}$ ).
\end{abstract}

Key words: Cyprus, golden oak, guide curve method, site quality.

\section{RESUMEN}

El roble dorado (Quercus alnifolia) es la especie endémica de Chipre ecológicamente más importante; por lo tanto, el desarrollo de curvas de índice de sitio para la clasificación de los árboles en calidades de sitio será de utilidad para la manejo racional y el monitoreo de los hábitats naturales de esta especie. El objetivo de este trabajo fue desarrollar curvas de índice de sitio para roble dorado. De áreas de distribución natural de roble dorado en Chipre, fueron seleccionados al azar 70 árboles dominantes y se cortaron; para cada árbol muestreado se llevó a cabo un análisis de tallo. Cuarenta y dos modelos de regresión lineal y no lineales se probaron para el ajuste de los datos de edad-altura, y de estos fue elegido el más adecuado para el desarrollo de una curva guía; entonces, basado en dicha curva, se desarrolló un conjunto de curvas anamórficas de índices de sitio. El modelo edad-altura seleccionado fue: $\hat{h}=\frac{t^{2}}{29.576+5.315 t+0.091 t^{2}}$. A la edad clave de 40 años, el modelo seleccionado estimó una altura de 4 m (SI4). Usando el modelo seleccionado como curva guía para el desarrollo de curvas anamórficas de índice de sitio, fueron trazadas dos curvas más: SI3 (edad clave de 40 años, altura estimada del árbol: $3 \mathrm{~m}$ ) y SI5 (edad clave de 40 años, altura estimada del árbol: $5 \mathrm{~m}$ ).

Palabras clave: Chipre, roble dorado, método de curva guía, calidad del sitio.

\section{INTRODUCTION}

The golden oak (Quercus alnifolia Poech) is the most important evergreen sclerophyllous forest shrub of Cyprus. It is an endemic species and forms pure stands or is established as understorey to stands of Pinus brutia, Pinus nigra and Cedrus brevifolia (Meikle 1976, Barbero and Quézel 1979, Knopf 2008). In some cases golden oak trees create dense stands presenting dense canopy. According to Cyprus Department of Forests, the demand for fuelwood in the island is very high; hence, if the golden oak dense stands are appropriately managed, they may be a source of good quality fuelwood. Moreover, the golden oak has considerable ecological importance (Neophytou 2010, Anagiotos et al. 2012).
It grows in steep and degraded soils preventing soil erosion, and its fruit is a source of food for fauna and micro-fauna (Neophytou 2010). Golden oak occurs exclusively on Troodos mountain of Cyprus ${ }^{1}$, at altitudes from $400 \mathrm{~m}$ to $1,800 \mathrm{~m}$. Its total area of distribution is 23,700 ha (Esser 1996).

The habitat type "Scrub and low forest vegetation of Quercus alnifolia (9390)" is a priority habitat of Annex I, Council Directive 92/43/EEC. Therefore, large forest expanses are included in the Natura 2000 network to protect, among others, the endemic forests of golden oak (under a project entitled "Establishment of a Plant Micro-Reserve Network in Cyprus", IUCN 2012). From national and

http://www.moa.gov.cy/moa/fd/fd.nsf/ (in Greek). 
community law, Cyprus is bound to observe habitats that joined in the Natura 2000 network and every three years must submit a report to the European Commission. In the context of the management plan of Paphos, the Cyprus Department of Forests Service is committed to submitting a monitoring plan of the habitat of the species included in the Natura 2000 network (Loizou 2010).

More studies have been conducted regarding species phytosociology (Sotiriou 2010) and genetics-taxonomy (Toumi and Lumaret 2001, Lumaret et al. 2002, Neophytou et al. 2007, 2008, 2011ab, Neophytou 2010, Loizides 2011), although only one study of species site quality classification (Loizou 2010). Considering the importance of the species, it is necessary to develop assistive tools that will be used for the rational management and monitoring of natural habitats of the golden oak.

The aim of this study is to develop site index curves for the golden oak species, for classification of the golden oak trees to site qualities. Among various techniques for developing site index curves, the anamorphic method is considered appropriate where remeasured permanent plot data for forest stands are lacking (Carmean 1972); therefore, this method is used in the present study.

\section{METHODS}

From areas of natural spread of golden oak in Cyprus (pure shrub forests of golden oak and open areas of open sparse Pinus brutia Ten. forests; not Pinus brutia stands where golden oak is established as understorey), dominant trees, as defined in Smith et al. 1997, were destructively sampled with random sampling, at elevations from $500 \mathrm{~m}$ to $1,700 \mathrm{~m}$. Sample size was 60 trees. All areas belong to Troodos Mountain, which is an ophiolite complex (a term used to describe a group of igneous rocks). These areas are generally characterized by a Mediterranean climate; however, in higher altitudes temperature is lower and precipitation is higher, compared to lower altitudes. Specifically, annual rainfall and mean yearly temperature at the lowest elevations are $507.9 \mathrm{~mm}$ and $18.5^{\circ} \mathrm{C}$ (Lefkara meteorological station, $420 \mathrm{~m}$ a.s.l.) respectively. The corresponding values for the highest elevations are $1047.9 \mathrm{~mm}$ and $10.4{ }^{\circ} \mathrm{C}$, respectively (Troodos meteorological station, $1,725 \mathrm{~m}$ a.s.l.). Meteorological data were provided by the Cyprus Meteorological Service and concern the period 1980 - 2010.

Almost all selected trees were multi-stemmed. These 60 trees were considered to represent good, medium and poor site qualities (20 trees were randomly selected from each site quality). The classification of an area in terms of site qualities was based on topographic position. Topographic features are related to site quality (see Dafis 1986, Barnes et al. 1998) and soil depth (Dafis 1986, Papalexandris and Milios 2010). The areas in gentle (gradual) slope and those located near streams were characterized as good quality sites, because it is considered that there is enough soil depth and moisture. Poor site qualities are located in areas close to or over ridges, which are characterized by shallow and usually quite eroded lands (Dafis 1986). Medium site qualities were marked areas located in the middle of slopes.

From each sampled tree, the tallest stem was cut and cross-sectional discs were cut and taken from the ground level height and every $1 \mathrm{~m}$ up to the bole. The last disc was cut from the $2 \mathrm{~cm}$ bole diameter. The number of annual growth rings was counted in each cross sectional disc using a stereoscope, with the LINTAB system of RinnTech and the program TSAP-Win (Rinn 2003). The resolution achieved was $1 / 100 \mathrm{~mm}$. For each sampled tree a stem analysis was conducted, calculating the tree height at each age using the improved version of Carmean's formula (Carmean 1972, Newberry 1991).

Forty-two linear and non-linear regression models were tested for fit-to-height/age data (Kitikidou 2008) and, from these, the most suitable was chosen for the development of a guide curve. With the guide curve method an average curve is created, and a set of anamorphic site indices can later be created based on this curve (Palahí et al. 2004, Kitikidou et al. 2011, 2012, 2014). Firstly, hypothesis testing was used for model comparison; subsequently, biological rationale was taken into account. Finally, model selection was based on statistical criteria calculation: nine criteria were used for model comparison (Kitikidou 2005, table 1). Model selection included several consecutive steps. Firstly, we checked the significance of regression coefficients; afterwards, we checked for unrealistic (negative) estimations for the dependent variable (height). Finally, we calculated the comparison criteria and made a decision.

\section{RESULTS}

Height of sampled trees ranged between 3.30 and $11.60 \mathrm{~m}$, while age ranged between 35 and 134 years (table 2).

The regression coefficients of the 42 models were significant, except for eight $(P>0.05$ for linear models, confidence intervals included zero for nonlinear models). From the remaining 34 models, 20 gave unrealistic estimations for height, and were therefore rejected. Comparison criteria values for the remaining 14 models are given in table 3 (best values for each criterion are marked with *).

Based on the results of table 3, model 8 was chosen as the most appropriate for the guide curve development. The selected height/age model, which was a non-linear model, was: $\hat{h}=\frac{t^{2}}{29.576+5.315 t+0.091 t^{2}}$. The mean annual increment from stem analyses was equal to $0.109 \mathrm{~m}$, corresponding to a base age of 40 years. At 40 years the selected model estimated a height of $4 \mathrm{~m}$ (SI4). Using the selected model as the guide curve for the development of anamorphic site index curves, we drew two more curves: SI3 (at the age of 40 years the estimated tree height is $3 \mathrm{~m}$ ) and SI5 (at the age of 40 years the estimated tree height is $5 \mathrm{~m}$ ) (figure 1). 
Table 1. Comparison criteria of regression models.

Criterios de comparación de modelos de regresión.

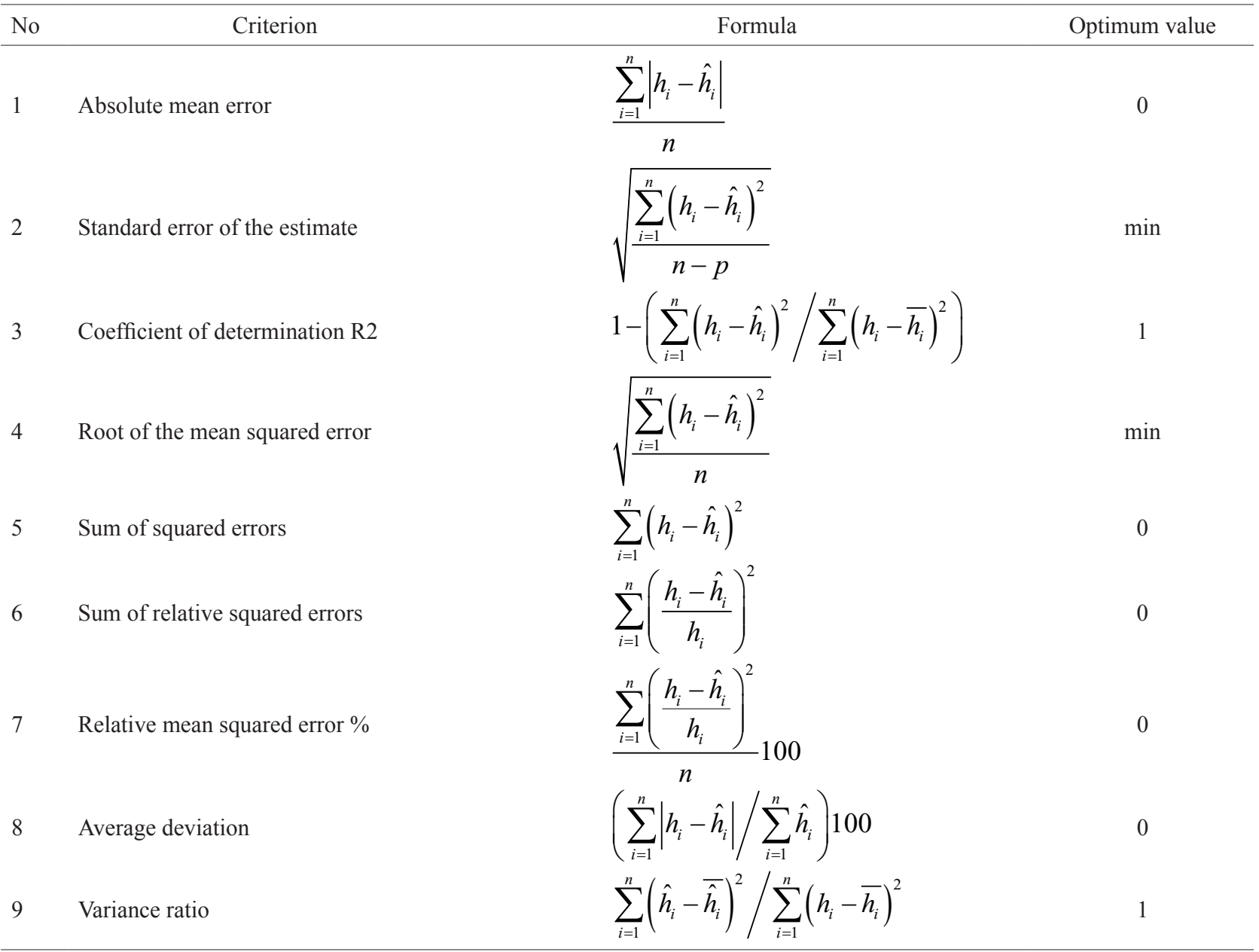

Where: $h=$ measured height from stem analyses $(\mathrm{m}) ; \hat{h}=$ estimated height $(\mathrm{m}), \bar{h}=$ average height from stem analyses, $\overline{\hat{h}}=$ average estimated height; $p=$ number of regression coefficients; $n=$ number of observations from stem analyses ( 4,086 age/height pairs).

Table 2. Summary statistics of the sampled trees.

Resumen de las estadísticas de los árboles muestreados.

\begin{tabular}{lrcccc}
\hline \multicolumn{1}{c}{ Variable } & Mean & Standard deviation & Minimum & Maximum & Number of trees \\
\hline Height $(\mathrm{m})$ & 6.38 & 2.34 & 3.30 & 11.60 & 60 \\
Age (years) & 68.10 & 23.65 & 35.00 & 134.00 & 60 \\
\hline
\end{tabular}

It is found that $67 \%$ of the sampled trees classified in the good site quality, based on topographic position, agree with the classification based on the site index curves developed in this study (table 4). Compatibility percentages for the medium and poor site qualities are $33 \%$ and $67 \%$, respectively. In the total of 60 trees, only 34 -classification based on topographic position- agree with the classification based on the site index curves (57\%). Loizou (2010) reached similar conclusions (corresponding percentages $75 \%, 35 \%, 53 \%$; in total $49 \%$ ).

\section{DISCUSSION AND CONCLUSIONS}

Loizou (2010) gives similar site index curves for golden oak, compared with our study (figure 2); the guide curve SI4 (medium site quality) has the same form: $h=\frac{t^{2}}{b_{0}+b_{1} t+b_{2} t^{2}}$, with different estimations for regression coefficients. The base age is also the same (40 years). In Loizou (2010), the height growth rate is bigger than that of our study, in good and medium site qualities. This is pro- 
Table 3. Results via comparison criteria.

Resultados a través de criterios de comparación.

\begin{tabular}{|c|c|c|c|c|c|c|c|c|c|c|}
\hline & Criterion & 1 & 2 & 3 & 4 & 5 & 6 & 7 & 8 & 9 \\
\hline & Optimum & 0 & $\min$ & 1 & $\min$ & 0 & 0 & 0 & 0 & 1 \\
\hline & Model & & & & & & & & & \\
\hline 1 & $\hat{h}=b_{0}+b_{1} t+b_{2} t^{3}$ & 1.064 & $1.456^{*}$ & $0.882 *$ & 53.718 & 8656.8 & 1010.6 & 24.7 & 29.927 & 0.853 \\
\hline 2 & $\hat{h}=b_{1} t+b_{2} t^{2}$ & 1.062 & 1.459 & $0.882 *$ & 65.909 & 8688.1 & 1067.9 & 26.1 & 29.870 & 0.855 \\
\hline 3 & $\hat{h}=b_{0}+b_{\sqrt{t}}+b_{2} t$ & 1.158 & 1.544 & 0.867 & 56.952 & 9730.6 & 26351.1 & 644.9 & 32.571 & 0.555 \\
\hline 4 & $\hat{h}=b_{0}+b \frac{1}{t}+b \frac{1}{t^{2}}$ & 1.470 & 1.861 & 0.807 & 68.665 & 14144.8 & 57065.8 & 1396.6 & 41.360 & 0.485 \\
\hline 5 & $\hat{h}=b_{0}+b_{1} \ln t+b_{2}(\ln t)^{2}$ & 1.070 & 1.460 & $0.882 *$ & 53.846 & 8698.2 & 2162.2 & 52.9 & 30.111 & 0.800 \\
\hline 6 & $\hat{h}=b_{1}\left[1-e^{\left(-b_{2} t\right)}\right.$ & 1.068 & 1.458 & $0.882 *$ & 65.865 & 8676.5 & 1239.7 & 30.3 & 29.842 & 0.848 \\
\hline 7 & $\hat{h}=b_{1} \mid 1-e^{\left(-b_{2} t^{t_{3}}\right)}$ & $1.061 *$ & $1.456^{*}$ & $0.882 *$ & 53.702 & 8651.7 & 919.2 & 22.5 & $29.810^{*}$ & 0.868 \\
\hline 8 & $\hat{h}=\frac{t^{2}}{b_{0}+b_{1} t+b_{2} t^{2}}$ & 1.063 & $1.456^{*}$ & $0.882 *$ & $53.701 *$ & $8651.5^{*}$ & $840.1^{*}$ & $20.6^{*}$ & 29.943 & 0.892 \\
\hline 9 & $\hat{h}=\frac{t}{b_{0}+b_{1} t+b_{2} t^{2}}$ & 1.064 & 1.457 & $0.882 *$ & 53.736 & 8662.6 & 1126.9 & 27.6 & 29.823 & 0.853 \\
\hline 10 & $\hat{h}=\frac{t^{2}}{\left(b_{0}+b_{1} t\right)^{2}}$ & 1.066 & $1.456^{*}$ & $0.882 *$ & 65.815 & 8663.3 & 852.2 & 20.9 & 30.155 & 0.896 \\
\hline 11 & $\hat{h}=e^{\left(b_{0}+b_{1} \frac{1}{t}\right)}$ & 1.109 & 1.476 & 0.879 & 66.698 & 8897.4 & 1159.9 & 28.4 & 31.808 & 0.900 \\
\hline 12 & $\hat{h}=b_{1} e^{\left(\frac{t}{t}\right)}$ & 1.109 & 1.476 & 0.879 & 66.698 & 8897.4 & 1159.9 & 28.4 & 31.808 & 0.900 \\
\hline 13 & $\hat{h}=b_{1} e^{\left(\frac{\sigma_{2}}{t^{b_{3}}}\right)}$ & 1.066 & 1.457 & $0.882 *$ & 65.820 & 8664.5 & 918.8 & 22.5 & 30.081 & $0.903^{*}$ \\
\hline 14 & $\hat{h}=b_{1} e^{\left(-b_{2} t\right)}$ & 1.385 & 1.729 & 0.834 & 78.116 & 12204.2 & 121902.1 & 2983.4 & 38.169 & 0.256 \\
\hline
\end{tabular}

Note: Models 11 and 12 were found to give identical estimations. $\hat{h}$ : estimated height (m), $t$ : age (years), $b_{i}$ : regression coefficients. Best values for each criterion are marked with *.

Table 4. Comparison of distinguishing site qualities based on site index curves and topographic position.

Comparación de las calidades de sitio distintivas basadas en las curvas de índice de sitio y posición topográfica.

\begin{tabular}{|c|c|c|c|c|c|c|c|c|c|}
\hline \multirow{2}{*}{$\begin{array}{l}\text { Classification based on site } \\
\text { index curves }\end{array}$} & \multicolumn{3}{|c|}{ I (good site quality) } & \multicolumn{3}{|c|}{ II (medium site quality) } & \multicolumn{3}{|c|}{ III (poor site quality) } \\
\hline & \multicolumn{3}{|c|}{24} & \multicolumn{3}{|c|}{18} & \multicolumn{3}{|c|}{18} \\
\hline \multirow{2}{*}{$\begin{array}{l}\text { Classification based on } \\
\text { topographic position }\end{array}$} & I & II & III & I & II & III & I & II & III \\
\hline & 16 & 8 & 0 & 4 & 6 & 8 & 0 & 6 & 12 \\
\hline $\begin{array}{l}\text { Compatibility of classification } \\
\text { based on topographic position }\end{array}$ & $67 \%$ & & & & $33 \%$ & & & & $67 \%$ \\
\hline
\end{tabular}



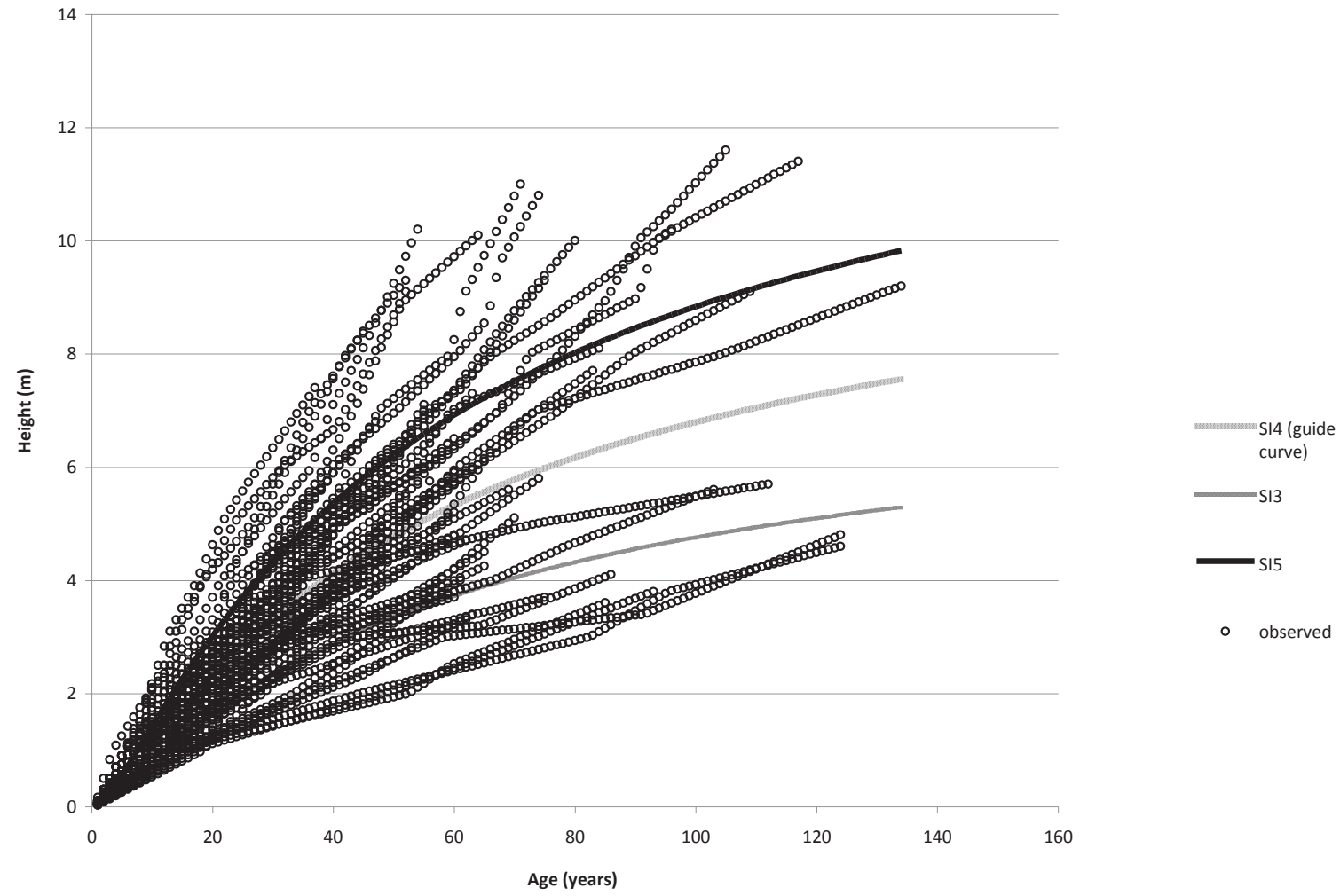

Figure 1. Site index curves for Quercus alnifolia.

Curvas de índice de sitio para Quercus alnifolia.
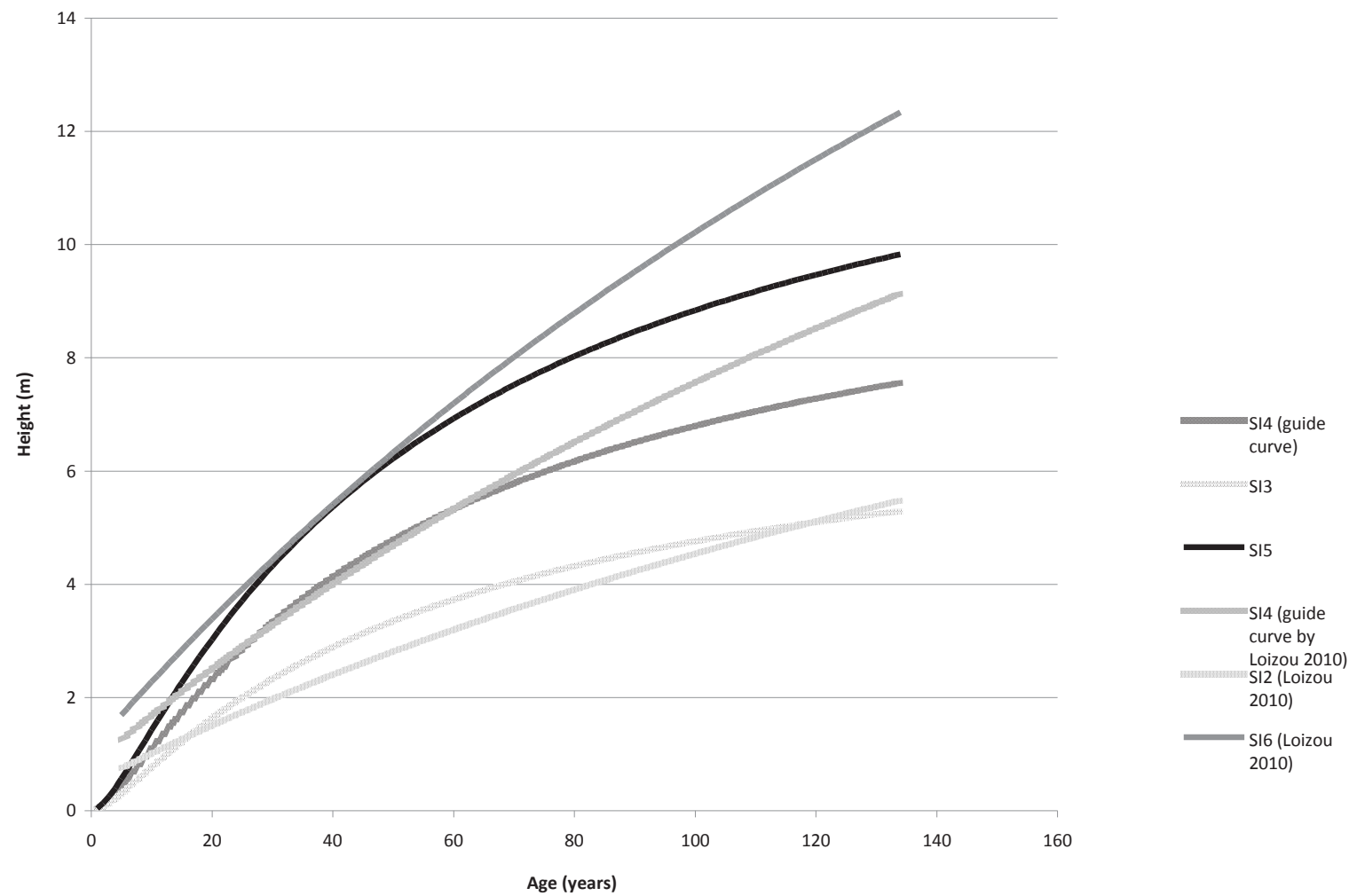

Figure 2. Comparison of site index curves for Quercus alnifolia (Loizou 2010 and present study).

Comparación de curvas de índice de sitio para Quercus alnifolia (Loizou 2010 and presente estudio). 
bably due to a) the smaller sample size (in Loizou (2010) 45 trees were measured, while in our study we re-measured these 45 trees and we measured 15 more), and b) to less accurate measurements (the number of annual growth rings was counted using a magnifier lens in Loizou (2010), and a stereoscope in our study).

In the study of Milios et al. (2012), where, among others, the effect of site productivity on the height growth of young Populus tremula L. clonal ramets was investigated, the distinction of areas in two site productivity categories using topographical features was verified by the height growth of dominant ramets. Moreover, the classification of site qualities into good and medium using topographical characteristics and soil depth made by Adamopoulos et al. (2009), in a reforestation of Pinus brutia in northeastern Greece, was verified by site index curves of a neighboring area and height growth data of young dominant pines. However, the classification of site qualities based on topographic position and site index curves, especially in more than two categories, may have medium compatibility, as in the present study. In the present study, the medium compatibility of topographic position and site index curve classifications ( $57 \%$ ) is probably due to the fact that similar soil depths, in some cases, represent different productivity sites for golden oak. Topographic position was used as soil depth surrogate and consequently as site productivity surrogate. In areas with long dry periods in summer, soil depth and its water storing capacity are factors that are strongly related to soil and site productivity (Dafis 1986, Hatzistathis and Dafis 1989); though, as noted in the methods section, data were collected in areas with different climate conditions. In the case of sampled trees that were cut in high elevation areas, soil depth was less significant for site productivity than in lower elevation areas, since summer aridity is decreasing as elevation increases. As a result, a soil with a medium depth in lower elevations may represent a lower productivity site, compared to a soil with the same depth in higher elevations. In higher elevations, the soil water storing capacity is not crucial for the growth of trees, since water availability is probably an insignificant growth limiting factor in summer. For this reason it is necessary to develop, whenever possible, site index curves with statistical methods.

In the present study, regardless of the fact that only the $57 \%$ of the trees were classified correctly, based on topographic position, topography affects site quality. None of the trees that were cut in gentle slope or areas located near streams was classified in poor site quality by site index curves, while none of the trees that were cut in areas close to or over ridges was classified in good site quality.

Site quality influences many attributes of forest stands as well as the competition ability of species (see Dafis 1986, Oliver and Larson 1996). Moreover, in different site productivity regimes, different treatments may be necessary for the conservation of a certain species stands (see Milios et al. 2007, 2011, Papalexandris and Milios 2010).

\section{ACKNOWLEDGEMENTS}

We wish to thank the Forests Department of Cyprus for their cooperation.

\section{REFERENCES}

Adamopoulos S, E Milios, D Doganos, I Bistinas. 2009. Ring width, latewood proportion and dry density in stems of $\mathrm{Pi}$ nus brutia Ten. European Journal of Wood and Wood Products 67(4): 471-477.

Anagiotos G, M Tsakaldimi, P Ganatsas. 2012. Variation in acorn traits among natural populations of Quercus alnifolia, an endangered species in Cyprus. Dendrobiology 68: 3-10.

Barbero M, P Quézel. 1979. Contribution à l'étude de groupements forestiers de Chypre. Documents Phytosociologiques IV: 9-35.

Barnes B, V Zak, S Denton, S Spurr. 1998. Forest Ecology. $4^{\text {th }}$ ed. New York, USA. John Wiley and Sons. 774 p.

Carmean W. 1972. Site index curves for upland oaks in the Central States. Forest Science 18: 109-120.

Council Directive 92/43/EEC of 21 May 1992 on the conservation of natural habitats and of wild fauna and flora. EURLex. European Union Law. 22-07-1992.

Dafis S. 1986. Forest Ecology. Thessaloniki, Greece. GiahoudisGiapoulis Publications. p. 443 (in Greek).

Esser A. 1996. Quercus alnifolia Poech. Monographie der auf Zypern endemischen Erlenblattrigen Eiche. Diploma thesis. Göttingen, Germany. Georg-August University of Göttingen Germany.

International Union for Conservation of Nature (IUCN). 2012. Establishment of a Plant Micro-Reserve Network in Cyprus. Available in http://iucn.org/about/union/secretariat/ offices/europe/?10340/Establishment-of-a-Plant-MicroReserve-Network-in-Cyprus

Hatzistathis A, S Dafis. 1989. Reforestations - Forest nurseries. Thessaloniki, Greece. Giahoudi-Giapouli. 265 p. (in Greek).

Kitikidou K. 2005. Applied statistics with use of the SPSS statistical package. Thessaloniki, Greece. Tziola Publications. 288 p. (in Greek).

Kitikidou K. 2008. Forest biometrical models for SPSS. Available in http://www.spsstools.net/Tutorials/kitikidou.doc

Kitikidou K, D Bountis, E Milios. 2011. Site index models for Calabrian pine (Pinus brutia Ten.) in Thasos island, Greece. Ciência Florestal 21(1): 125-131.

Kitikidou K, M Kaymakis, E Milios. 2012. Site index curves for young Populus tremula stands on Athos Peninsula (northern Greece). Turkish Journal of Agriculture and Forestry 36: 55-63.

Kitikidou K, E Milios, E Tsirekis, E Pipinis, A Stampoulidis. 2014. Site quality assessment of degraded Quercus frainetto stands in central Greece. iForest - Biogeosciences and Forestry: e1-e6.

Knopf H. 2008. Quercus alnifolia Poech. Enzyklopädie der Holzgewächse: 1-7.

Loizides M. 2011. Quercus alnifolia: the indigenous Golden Oak of Cyprus and its fungi. Field Mycology 12(3): 81-88.

Loizou L. 2010. Development of assistive management tools in the management of Quercus alnifolia. Cyprus Forestry 
Department Report. Cyprus. Forestry Department, Sub-department of Management and Information Technology. $43 \mathrm{p}$.

Lumaret R, C Mir, H Michaud, V Raynal. 2002. Phylogeographical variation of chloroplast DNA in holm oak (Quercus ilex L.). Molecular Ecology 11: 2327-2336.

Meikle R. 1976. Flora of Cyprus. London, UK. Bentham Moxon Trust, Royal Botanic Gardens.

Milios E, P Petrou, E Andreou, E Pipinis. 2011. Is facilitation the dominant process in the regeneration of the Juniperus excelsa M. Bieb. stands in Cyprus? Journal of Biological Research 16: 296-303.

Milios E, E Pipinis, P Petrou, S Akritidou, K Kitikidou, P Smiris. 2012. The influence of position and site on the height growth of young Populus tremula L. ramets in low elevation formations in Northeastern Greece. Notulae Botanicae Horti Agrobotanici Cluj-Napoca 40(2): 302-307.

Milios E, E Pipinis, P Petrou, S Akritidou, P Smiris, M Aslanidou. 2007. Structure and regeneration patterns of the Juniperus excelsa Bieb. stands in the central part of the Nestos valley in the northeast of Greece, in the context of anthropogenic disturbances and nurse plant facilitation. Ecological Research 22: 713-723.

Neophytou C. 2010. A study of genetic differentiation and hybridization among oak species with divergent ecological and evolutionary profiles. $\mathrm{PhD}$ thesis. Freiburg, Germany. Faculty of Forest and Environmental Sciences, Albert-Ludwigs-Universität. $58 \mathrm{p}$.

Neophytou C, F Aravanopoulos, S Fink, A Dounavi. 2011a. Interfertile oaks in an island environment. II. Limited hybridization between Quercus alnifolia Poech and Q. coccifera L. in a mixed stand. European Journal of Forest Research 130: 623-635.

Neophytou C, A Dounavi, S Fink, F Aravanopoulos. 2011b. I. High nuclear genetic differentiation and high degree of chloroplast DNA sharing between $Q$. alnifolia and
Q. coccifera in Cyprus. A multipopulation study. European Journal of Forest Research 130: 543-555.

Neophytou C, A Douvani, F Aravanopoulos. 2008. Conservation of Nuclear SSR Loci reveals hight affinity of Quercus infectoria ssp. veneris A. Kern (Fagaceae) to section Robur. Plant Molecular Biology Reporter 26: 133-141.

Neophytou C, G Palli, A Dounavi, F Aravanopoulos. 2007. Morphological differentiation and hybridization between Quercus alnifolia Poech and Quercus coccifera L. (Fagaceae) in Cyprus. Silvae Genetica 56(6): 271-277.

Newberry J. 1991. A note on Carmean's estimate of height from stem analysis data. Forest Science 37(1): 368-369.

Oliver C, B Larson. 1996. Forest Stand Dynamics. New York, USA. John Wiley and Sons. 520 p.

Palahí M, M Tomé, T Pukkala, A Trasobares, G Montero. 2004. Site index for Pinus sylvestris in north-east Spain. Forest Ecology and Management 187(1): 35-47.

Papalexandris C, E Milios. 2010. Analysis of natural Fagus sylvatica L.s.l. regeneration in low elevation stands located in the central part of Evros region in the Northeast of Greece. Is sprout origin regeneration significant for the species maintenance? Plant Biosystems 44: 784-792.

Rinn F. 2003. TSAP-Win: time series analysis and presentation for dendrochronology and related applications. Version 0.55 User reference. Heidelberg, Germany. $91 \mathrm{p}$.

Smith D, B Larson, M Kelty, M Ashton. 1997. The Practice of Silviculture. Applied Forest Ecology. New York, USA. John Willey and Sons. 560 p.

Sotiriou A. 2010. Phytosociological research of the national forest park of mountain Troodos of Cyprus. PhD thesis. Thessaloniki, Greece. Faculty of Forestry and Natural Environment, Aristotle University. 217 p.

Toumi L, R Lumaret. 2001. Allozyme characterisation of four Mediterranean evergreen oak species. Biochemical Systematics and Ecology 29: 799-817. 
